\title{
Endothelial progenitor cells and integrins: adhesive needs
}

Francisco Caiado ${ }^{1,2,3}$ and Sérgio Dias ${ }^{1,2,3^{*}}$

\begin{abstract}
In the last decade there have been multiple studies concerning the contribution of endothelial progenitor cells (EPCS) to new vessel formation in different physiological and pathological settings. The process by which EPCs contribute to new vessel formation in adults is termed postnatal vasculogenesis and occurs via four inter-related steps. They must respond to chemoattractant signals and mobilize from the bone marrow to the peripheral blood; home in on sites of new vessel formation; invade and migrate at the same sites; and differentiate into mature endothelial cells (ECs) and/or regulate pre-existing ECs via paracrine or juxtacrine signals. During these four steps, EPCs interact with different physiological compartments, namely bone marrow, peripheral blood, blood vessels and homing tissues. The success of each step depends on the ability of EPCs to interact, adapt and respond to multiple molecular cues. The present review summarizes the interactions between integrins expressed by EPCS and their ligands: extracellular matrix components and cell surface proteins present at sites of postnatal vasculogenesis. The data summarized here indicate that integrins represent a major molecular determinant of EPC function, with different integrin subunits regulating different steps of EPC biology. Specifically, integrin $\alpha 4 \beta 1$ is a key regulator of EPC retention and/or mobilization from the bone marrow, while integrins $\alpha 5 \beta 1, \alpha 6 \beta 1, \alpha \vee \beta 3$ and $\alpha \vee \beta 5$ are major determinants of EPC homing, invasion, differentiation and paracrine factor production. $\beta 2$ integrins are the major regulators of EPC transendothelial migration. The relevance of integrins in EPC biology is also demonstrated by many studies that use extracellular matrix-based scaffolds as a clinical tool to improve the vasculogenic functions of EPCs. We propose that targeted and tissue-specific manipulation of EPC integrin-mediated interactions may be crucial to further improve the usage of this cell population as a relevant clinical agent.
\end{abstract}

\section{Review}

Postnatal vasculogenesis and endothelial progenitor cells The cardiovascular system is the first functional organ system to develop in the vertebrate embryo and is required for embryonic survival to regulate multiple homeostatic functions in the developing embryo [1]. New blood vessel formation (neovascularization) is an essential mechanism determining the formation, but also the maintenance, of the cardiovascular system. It is thought to depend mainly on two processes, angiogenesis and vasculogenesis.

Angiogenesis is the process by which new vessels are formed by the activation, proliferation and migration of endothelial cells (ECs). Vasculogenesis is defined as the process by which new vessels are generated, by the

\footnotetext{
* Correspondence: sergidias@ipolisboa.min-saude.pt

'Angiogenesis Laboratory, CIPM, Instituto Português de Oncologia Francisco Gentil, EPE, Lisboa, Portugal

Full list of author information is available at the end of the article
}

migration and differentiation of vascular endothelial growth factor receptor 2 positive (VEGFR-2+) mesodermal precursors, termed angioblasts and/or hemangioblasts, into ECs that coalesce to form a primary vascular plexus during embryonic development [2].

The existence of an equivalent process during adulthood - postnatal vasculogenesis - has been intriguing vascular and hematologic researchers since the early 20th century, when the first studies describing blood vessel formation from peripheral blood (PB) and bonemarrow (BM) mononuclear cells were published. These studies suggested the existence of a population of cells in the PB and/or BM capable of generating ECs when cultured under specific conditions [3-5]. However, it was only in 1997 that Asahara et al. [6] isolated and characterized CD34+ or VEGFR-2+ cell populations for the first time, derived from $\mathrm{PB}$ capable of differentiating into ECs in vitro when plated on fibronectin (FN) and exposed to angiogenic growth factor stimuli, namely
C Biomed Central

(c) 2012 Caiado and Dias; licensee BioMed Central Ltd. This is an Open Access article distributed under the terms of the Creative Commons Attribution License (http://creativecommons.org/licenses/by/2.0), which permits unrestricted use, distribution, and reproduction in any medium, provided the original work is properly cited. 
vascular endothelial growth factor (VEGF). Accordingly, using an in vivo animal model of hind limb ischemia, these authors showed that CD34+ and VEGFR-2+ cells were incorporated into newly formed vessels and acquired the expression of EC antigens. These cells where thus termed endothelial progenitor cells (EPCs) [6]. In accordance, Shi Q et al [7] reported the existence of 'circulating bone marrowderived endothelial progenitor cells' in the adult and showed that these cells were derived from BM. Circulating BM-derived EPCs were defined as a subset of CD34+ hematopoietic stem cells with the ability to differentiate into the endothelial lineage and express endothelial marker such as von Willebrand Factor (vWF) and incorporate acetylated Low Density Lipoprotein (Ac-LDL). Most convincingly, these authors showed that bone marrow-transplanted genetically tagged cells contributed to the endothelialization of a Dacron graft placed on the descending thoracic aorta in dogs. Later, in 2000, Peichev et al. added to the molecular definition of human EPCs, showing that these express CD133+ (prominin), CD34+ and VEGFR-2+, and are present in adult mobilized PB, cord blood and also fetal livers. This pioneer study proposed that CD133, together with other endothelial markers, including VEGFR2 and CD34, could be used to distinguish EPCs from mature ECs and also from other tissue stem cells [8]. The proof of existence for EPCs and the demonstration of their ability to differentiate into mature ECs and incorporate blood vessels was a key finding to support the existence of postnatal vasculogenesis.

The biological significance of EPCs is supported by accumulating evidence from the last decade showing that this cell population contributes in a quantitative manner to postnatal vasculogenesis in multiple conditions These include physiological, such as neonatal tissue growth $[9,10]$, and pathological conditions, such as peripheral vascular disease [11], myocardial and limb ischemia [12,13], stroke [14], tissue regeneration [15-18], retinopathy [19], artherosclerosis [20] and tumor growth [21-24]. Given their significant biological contribution in different types of vascular pathologies, EPCs and their biology have been under intense investigation for the last decade. Most studies have focused on the molecular definition of EPCs, on the molecular mechanisms regulating EPC function, the quantitative determination of EPC contribution to physiological and/or pathological postnatal vasculogenesis and, more recently, on the clinical and therapeutic applications of this cell population.

In the next sections of this review we will update and resume some of these aspects with a major focus on the importance of integrin-mediated interactions (adhesion) on EPC biology and function.

\section{Molecular definition(s) of endothelial progenitor cells}

A consensus as to the markers that define EPCs has not been reached; different authors use various combinations of surface and functional markers to isolate and study EPCs in different contexts. In the context of this review, EPCs will be defined as BM-, PB-, cord blood- or fetal liver-derived nonendothelial cells that have stemness properties and markers (CD133+, CD34+, c-Kit+/Sca-1 + ); are capable of clonal expansion; and are able to differentiate into adherent ECs, acquiring endothelial properties and markers (CD146+, CD31+, CD105+, vWF+, tyrosine kinase with immunoglobulin-like and EGF-like domains-2+, vascular endothelial cadherin + and VEGFR2+) [25-27]. A more comprehensive definition of EPC markers is beyond the scope of this review.

\section{Endothelial progenitor cell biology and function during postnatal vasculogenesis}

Since EPCs were first described there have been numerous studies concerning their biology and function. In the last decade, it has been established that, in order to exert their 'vascular function', EPCs have to accomplish four distinct but interrelated steps. They must respond to chemoattractant signals and mobilize from the BM to the PB; home in on sites of vascular remodeling, repair and angiogenesis; invade and migrate at the same sites; and differentiate into mature ECs and/or regulate preexisting ECs via paracrine or juxtacrine signals [28].

Some of the major molecular regulators that determine these four steps have been identified (Figure 1). In

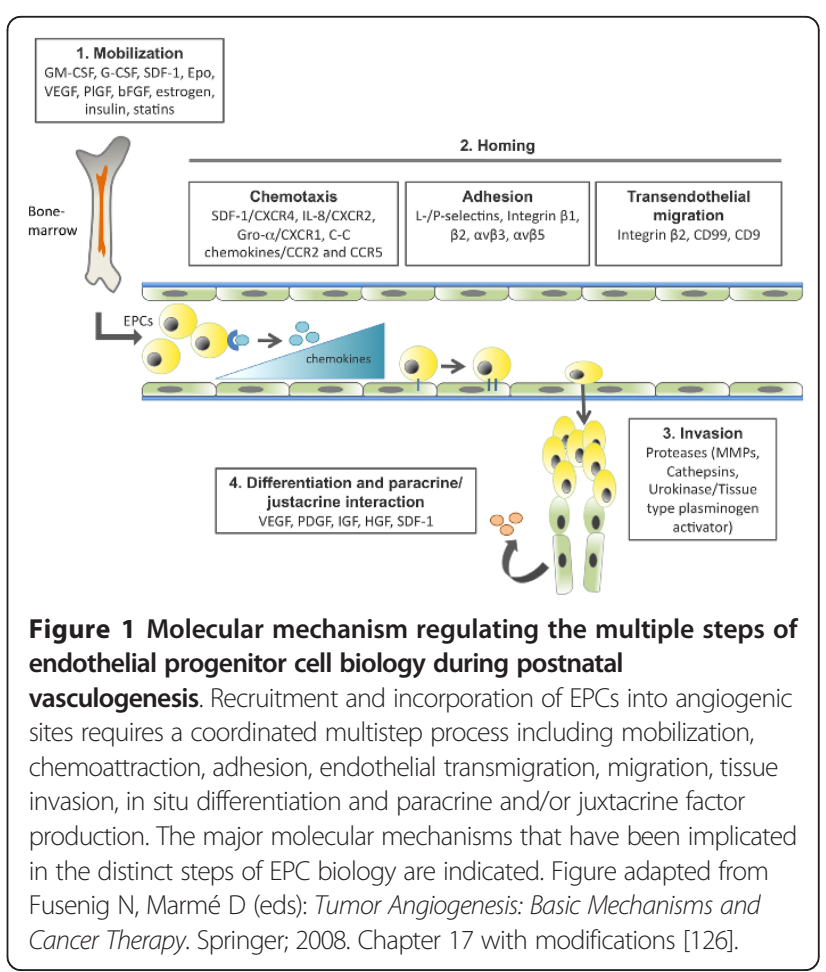


normal conditions, EPCs reside within a stem cell niche in the BM characterized by low oxygen tension [29] and high levels of stromal cell-derived factor-1 (SDF-1), a potent chemoattractant for EPCs that binds via the receptor CXC chemokine receptor type 4 (CXCR4) [30]. EPCs are mobilized from the BM in response to peripheral tissue hypoxia and trauma, which cause the production and release of EPC mobilizing factors such as granulocyte-monocyte colony stimulating factor, granulocyte colony stimulating factor, VEGF, basic fibroblast growth factor, placental growth factor, erythropoietin or SDF-1 to a concentration greater than that in the BM [28]. These factor act via the phosphoinositide 3-kinase/ protein kinase B (Akt) pathway to activate endothelial nitric oxide synthase, leading to an increased production of nitric oxide, which regulates the enzymatic activity of matrix metalloproteinases (MMPs) [31,32]. In particular, activated MMP-9 leads to the release of soluble kit ligand from EPCs in the BM, allowing the cells to move out to the peripheral circulation [33].

Once in circulation, EPCs home in on activated tissues in response to chemokine gradients that are formed in the tissue regions undergoing active remodeling. The major chemokines and respective receptors that regulate EPC activation and homing are SDF-1 and CXCR4; IL-8 and CXCR2; growth regulated oncogene- $\alpha$ and CXCR1; and $\mathrm{C}-\mathrm{C}$ chemokine and chemokine (C-C motif) receptors 2 and 5 [34-39]. Upon interaction with tissue-specific chemokines, EPCs become activated and initiate integrin-mediated adhesion to endothelial vascular cells and consequently transendothelial migration into sites of vascular and tissue remodeling. The major integrins and respective ligands that mediate these steps of EPC function will be discussed in detail in the present review.

Once circulating EPCs have crossed the endothelial monolayer, they need to migrate through the blood vessel basement membrane and through the interstitial extracellular matrix (ECM) in order to arrive at the specific niches where they can exert their functions. EPC invasion depends to a great extent on the activity of extracellular proteases that breakdown and remodel ECM components at the vessel basement membrane and also in the interstitial space. The major extracellular proteases involved in EPC invasion are members of the MMP family (in particular MMP-9 [40]), members of the cathepsin family (cathepsin L [41]) and also the serine protease urokinase-type plasminogen activator and tissue-type plasminogen activator [42].

When the EPCs arrive at sites of vessel remodeling they will contribute to new vessel formation and remodeling. The mechanisms that contribute to the functional activity of EPCs are still under investigation. However, functional activity of EPCs depends mainly on two processes: differentiation into mature ECs and direct incorporation into neovessels and/or production of paracrine and/or juxtacrine signals that promote interactions with pre-existing ECs and other cell types. The differentiation of EPCs into ECs is a very complex process that can be subdivided into three steps [43]. First, there is integrin-mediated adhesion to ECM components. The direct interaction between integrin $\alpha 5 \beta 1$ and FN in particular have been shown to be essential in the initial steps of EPC differentiation [44]. Second, there is growth factor-induced proliferation and survival: the VEGF family of growth factors and also the angiopoietin-tyrosine kinase with immunoglobulin-like and EGF-like domains 1 receptor pathway [45] have been implicated in the regulation of EPC proliferation and survival. Third, the maturation and acquisition of an endothelial phenotype is an essential step in EPC biology and depends mainly on the regulation of the transcription factor HoxA, which is transcriptionally regulated by histone deacetylases. Accordingly, HoxA9 has been shown to regulate the expression of the endothelial genes for endothelial nitric oxide synthase, VEGFR-2 and vascular endothelial cadherin [46]. Besides differentiating into ECs, EPCs have been shown to produce multiple paracrine factors such as VEGF, SDF-1, insulin-like growth factor 1 , monocyte chemotactic protein 1 (MCP-1), macrophage inflammatory protein $1 \alpha$ and platelet derived growth factor $[47,48]$. Altogether these factors can act on different cell types leading to an overall response that promotes angiogenesis and tissue regeneration.

\section{Integrin-extracellular matrix interactions in endothelial progenitor cells biology}

Throughout the main steps that regulate EPC function mobilization, homing, invasion and differentiation and/ or paracrine factor production - EPCs interact with different physiological compartments, namely BM, PB, blood vessels and homing tissues. Therefore what determines the success of each step is the ability of EPCs to interact, adapt and respond to multiple molecular cues present in each compartment. Considering this, although some of the molecular pathways regulating the multiple steps of EPC biology have been addressed (Figure 1), in the present review we will summarize the known contributions of structural and/or morphogenic signals to EPC biology, in particular the interaction between integrins expressed by EPCs and their ligands, ECM components and cell surface proteins present at sites of vascular repair/remodeling. We propose that targeted manipulation of integrin-ECM interactions in EPCs and at sites of vascular remodeling may contribute to the improvement of EPC-mediated vascular repair and function. 
The ECM is a non-cellular component present within all tissues and organs that provides not only an essential physical scaffold for the cellular constituents but also initiates crucial biochemical and biomechanical cues that determine cell differentiation, proliferation, survival, polarity and migration. It thus plays an essential role in tissue morphogenesis, differentiation and homeostasis [49]. The ECM is mainly composed of two main classes of macromolecules: proteoglycans and fibrous proteins [50,51]. The main fibrous ECM proteins are collagens, elastins, FNs and laminins. Proteoglycans (namely perlecan) fill the majority of the extracellular interstitial space within the tissue in the form of a hydrated gelatin. The direct effect of ECM components in cell behavior derives mainly from two ECM properties: their ability to bind directly to their cellular receptors, integrins and discoidin domain tyrosine kinase receptors - which in turn are signal transduction receptors; and their ability to bind and present growth factors as organized solidphase [49]. As mentioned earlier, in the present review we will focus mainly on the contribution of ECM-integrin interactions on EPC biology.

Integrins are a family of non-covalently associated heterodimeric transmembrane glycoprotein adhesion proteins which mediate cell-ECM and cell-cell interactions. Integrins are responsible for cellular tissue architecture and also function as signal transducers regulating survival, proliferation, differentiation and migratory signaling pathways. Each integrin is composed of two subunits: one $\alpha$ - (around 800 amino acids) and one $\beta$-subunit (approximately 1,000 amino acids). In higher vertebrates, eighteen $\alpha$ - and eight $\beta$-subunits combine to form more than 24 different integrin heterodimers. Heterodimer composition confers ligand specificity, with most integrins recognizing several ECM proteins that in turn bind to more than one integrin [52].

\section{Integrin expression in endothelial progenitor cells}

In agreement with multiple studies concerning the expression of integrin subunits on EPCs, we can define an integrin expression profile on EPCs. Accordingly, EPCs express integrin subunits $\alpha 1, \alpha 2, \alpha 3, \alpha 4, \alpha 5, \alpha 6$, $\alpha 9, \alpha v, \beta 1, \beta 2, \beta 3, \beta 5$ and $\beta 7$ [43,44,53-61]. Despite the expression of so many different integrin subunits by EPCs, it is apparent that some of these integrins can in fact be activated and/or upregulated at specific steps of EPC biology as reflex to the multiple molecular cues (tissue specific ECM and soluble factors) that may be present. This suggests that the integrin expression profile of EPCs is in fact a dynamic aspect of EPC biology reflecting the adaptation of these cells to different conditions. In the next sections we will summarize the reported functions of each integrin subunit in EPC biology (Table 1).

Integrin-mediated endothelial progenitor cell mobilization from the bone marrow - integrin subunits $\alpha 4$ and $\beta 3$ The main integrins regulating the mobilization of EPCs from the BM microenvironment are the $\alpha 4$ integrins. These have been proven essential for embryogenesis, hematopoiesis, lymphocyte homing and the recruitment of leukocytes to sites of inflammation [62]. The $\alpha 4$ integrins, $\alpha 4 \beta 1$ and $\alpha 4 \beta 7$ are most prominent on mononuclear leukocytes, but can also be expressed in neutrophils, hematopoietic stem cells and EPCs [63,64]. $\alpha 4 \beta 1$ mediates cell adhesion to vascular cell adhesion molecule-1 (VCAM-1) and to an alternatively spliced form of the extracellular matrix protein, FN [65]. $\alpha 4 \beta 7$ is important in lymphocyte homing to mucosal tissue by adhering to the gut homing receptor mucosa addressing cell adhesion molecule and it also binds to VCAM-1 and FN [66-68]. Concerning their role on EPC mobilization, it has been shown that in vitro usage of anti- $\alpha 4$ integrin

Table 1 Overview of the major integrin sub-units and respective ligands involved in endothelial progenitor cell biology.

\begin{tabular}{|c|c|c|c|}
\hline Integrin & Main ligand & Role on EPC biology & References \\
\hline$\alpha 4 \beta 1$ & FN; VCAM-1 & $\begin{array}{l}\text { Bone marrow retention and/or mobilization; } \\
\text { homing and/or adhesion to angiogenic sites }\end{array}$ & {$[63,72]$} \\
\hline$\alpha 5 \beta 1$ & FN & $\begin{array}{l}\text { Homing and/or adhesion to angiogenic sites; } \\
\text { invasion and migration; } \\
\text { differentiation and paracrine/juxtacrine interaction }\end{array}$ & {$[44,69,83,96-98]$} \\
\hline$\alpha 6 \beta 1$ & Laminin & $\begin{array}{l}\text { Homing and/or adhesion to angiogenic sites; } \\
\text { invasion }\end{array}$ & {$[56,87]$} \\
\hline$\beta 2$ integrins & Fibrin(ogen); ICAM-1/2 & $\begin{array}{l}\text { Homing and/or adhesion to angiogenic sites; } \\
\text { transendothelial migration }\end{array}$ & {$[72-74,90,91]$} \\
\hline$\alpha \vee \beta 3$ & RGD & $\begin{array}{l}\text { Homing and/or adhesion to angiogenic sites; } \\
\text { bone marrow retention and/or mobilization ( } \beta 3 \text { subunit) }\end{array}$ & {$[69,88,98]$} \\
\hline$\alpha \vee \beta 5$ & RGD & $\begin{array}{l}\text { Homing/adhesion to angiogenic sites; } \\
\text { differentiation and paracrine and/or juxtacrine interaction ( } \beta 5 \text { subunit) }\end{array}$ & {$[88,89,98,99]$} \\
\hline
\end{tabular}

EPC: endothelial progenitor cell; FN: fibronectin; ICAM-1/2: intercellular adhesion molecule 1/2; RGD: arginine-glycine-aspartate motif; VCAM-1: vascular cell adhesion molecule 1. 
antibody blocks and competes with the adhesive interactions between BM-derived EPCs and immobilized VCAM-1, FN (to a smaller extent) or BM stromal cells. Moreover, systemic administration of anti- $\alpha 4$ integrin antibody or conditional knockout of $\alpha 4$ integrin in the $\mathrm{BM}$ significantly increases the number of circulating EPCs, suggesting that this integrin is essential for retaining EPCs in the BM [63]. Interestingly, after ischemic injury, integrin $\alpha 4$ blockade results in an increase in the number of BM-derived EPCs present in the neovasculature at the ischemic tissue and augments the recovery of blood flow and tissue preservation. Altogether, these authors establish that $\alpha 4$ integrin plays an important role in BM-derived EPC mobilization and that functional disruption of $\alpha 4$ integrin-mediated EPC retention in the BM causes a shift toward a distribution of EPCs into circulation that favors neovascularization.

Another integrin subunit that has been implicated in the retention of EPCs in the BM is the integrin $\beta 3$. These integrins have essential roles in angiogenesis, hemostasis and in bone remodeling, being essentially expressed on ECs, platelets, osteoclasts and hematopoietic cells [52]. Concerning EPC mobilization, a recent paper by Watson et al. shows that $\beta 3$ integrins are necessary for the retention of EPCs in the BM, since wild-type mice receiving $\beta 3$ integrin-null $B M$ show increased EPCs mobilization to the PB and consequent increased tumor vascularization. However, a high proportion of the vessels are nonfunctional and therefore do not enhance tumor growth, further suggesting that integrin $\beta 3$ might affect other EPC properties besides BM mobilization [69].

\section{Integrin-mediated endothelial progenitor cells homing to} sites of vascular remodeling, repair and angiogenesis After being mobilized from the BM into the PB, EPCs become a small percentage of the circulating cells along with other hematopoietic populations. Considering this, EPCs must be specifically responsive to signals present at injury and remodeling ECs as opposed to signals present in normal and quiescent ECs. Recognizing such signals enables EPCs to home to sites of vessel injury and remodeling, where they become activated by local chemokines and cytokines, adhere to activated ECs or ECM components and incorporate and differentiate into newly formed vessels, or act via paracrine and/or juxtacrine interactions on pre-existing ECs. Direct evidence of EPC homing and incorporation into neovasculature has been addressed by Vajkoczy et al. using intravital fluorescence videomicroscopy and murine embryonic EPCs in a tumor model. According to this study embryonic EPC homing to tumor vasculature occurs mainly by sticking (active adhesion to tumor vasculature without affecting blood flow) and not by plugging tumor blood vessels (size restrictions or dead-end vascular sprouts), contrary to what happens in normal vasculature [70]. This data suggests that EPC homing is an active process involving direct interaction between molecular targets expressed on homing tissues and adhesion molecules, namely integrins, expressed by EPCs.

\section{$\beta 2$ integrins in endothelial progenitor cell homing}

There are numerous studies reporting the role of integrins during EPC homing to sites of neoangiogenesis. One of the major integrin subunits regulating EPC homing to active angiogenic sites is the $\beta 2$ integrin. $\beta 2$ integrins are described as leukocyte specific receptors, recognizing essentially multiple members of the intercellular adhesion molecule (ICAM) family and polysaccharides [71]. These integrins are essential for the regulation of hematopoiesis, leukocyte recruitment and inflammatory cells [52]. Despite the specificity of integrin $\beta 2$ expression in leukocytes, many studies have described its expression in EPCs [61,71-73]. In vitro adhesion studies show that $\beta 2$ integrins mediate the adhesion of adult PB-derived EPCs to pre-activated EC monolayers and also to ICAM-1 and fibrinogen. Additionally, the same study revealed that $\beta 2$ integrins and its activation status play an essential role not only in the homing of $\mathrm{BM}$-derived EPCs to ischemic tissues but also in the neovascularization capacity of these cells in vivo. Further supporting the role of integrin $\beta 2$ and its activation on EPC homing is the fact that the addition of pharmacological activators of exchange protein directly activated by cyclic AMP (a nucleotide exchange protein for rasrelated protein 1 that activates integrin conformation) to EPCs increases $\beta 2$-integrin-dependent adhesion to ICAM-1, migration on fibrinogen and, consequently, the homing and neovascularization-promoting capacity of intravenously injected EPCs [74].

\section{$\beta 1$ integrins in endothelial progenitor cell homing}

In spite of the described role of $\beta 2$ integrins on EPC homing, multiple studies have shown that its inhibition leads only to a partial inhibition of EPC homing, suggesting that other integrins may also regulate this essential step of EPC biology. One of the major integrin families regulating EPC homing to angiogenic sites is the $\beta 1$ integrins.

In particular integrin $\alpha 4 \beta 1$ is highly expressed in EPCs and has been shown to mediate in vitro adhesion of EPCs to pre-activated EC monolayers, specifically to VCAM-1 and cellular FN [63]. Furthermore, in in vivo models of breast cancer, inhibition of $\alpha 4 \beta 1$ integrin significantly blocks homing of BM-derived EPCs cells to tumor neovessels expressing its ligands FN and VCAM1 [72]. Interestingly, as mentioned before, $\alpha 4 \beta 1$ blockade can in fact mobilize EPCs from the BM and increase their number in the $\mathrm{PB}$, thus indicating that targeting 
this integrin can have a double effect, increasing EPC mobilization but decreasing their homing to angiogenic sites.

Besides recognizing molecular homing signals expressed by activated ECs, EPCs can recognize and adhere directly to exposed ECM components. $\alpha 5 \beta 1$ integrin is an FN receptor, which binds to the arginine-glycine-aspartic acid (RGD) motif region of FN [75]. Studies using various cell culture systems have suggested that $\alpha 5 \beta 1$ is involved in many cellular processes including cell proliferation, oncogenic transformation, assembly of FN-rich extracellular matrices, cell migration, regulation of gene expression, wound healing, T-cell activation, angiogenesis and embryogenesis - where it regulates mesodermal formation and function [76-80]. Integrin $\alpha 5 \beta 1$ is also highly expressed in EPCs and is directly involved in the homing of EPCs to denuded vessels, where its ligand FN rapidly accumulates [81]. Accordingly, treatment of EPCs with statins increases the expression levels of integrin $\alpha 5 \beta 1$, consequently increasing EPC homing to vascular injury sites and thus promoting re- endothelialization of these sites [59].

In agreement with the above, a recent report describes the direct interaction between EPCs integrin $\alpha 5 \beta 1$ and FN under laminar shear stress, suggesting that EPC adhesion to exposed FN on blood vessels can occur under physiological levels of shear stress [82]. The role of $\alpha 5 \beta 1$ in EPC homing is further supported in models of lung vascular injury, where these integrins, together with $\alpha 4 \beta 1$ integrin, mediate the homing and adhesion of EPCs to damaged pulmonary capillaries, further contributing to the repair of the endothelial barrier and preventing lung vascular damage [83].

Another $\beta 1$ integrin associated with EPC homing to sites of neovascularization is the integrin $\alpha 6 \beta 1 . \alpha 6 \beta 1$ integrin is a laminin-binding integrin that is essential for skin homeostasis [84], regulates endothelial tube formation [85] and also contributes to hematopoietic stem cell homing to the BM [86]. Concerning EPCs, a recent work by Bouvard et al. has shown that integrin $\alpha 6 \beta 1$ is directly regulated by VEGF and basic fibroblast growth factor and is necessary for EPC homing to ischemic skeletal muscle in vivo and to EPC adhesion to basement membrane components in vitro. According to these authors, vessel obstruction leads to reduced oxygen supply and consequent death and detachment of the ECs lining the walls, exposing the underlying basement membrane components (namely laminins). Exposed laminin may then function as a specific homing signal for EPCs expressing integrin $\alpha 6 \beta 1$, thus directing EPCs to sites of vascular injury where these cells can restore vascular integrity $[56,87]$.

\section{$\alpha v$ integrin in endothelial progenitor cell homing}

Integrins $\alpha v$ (namely $\alpha v \beta 3$ - and $\alpha v \beta 5$-integrins) also play a role in EPC homing to sites of vascular repair. $\alpha \mathrm{v}$ integrins are expressed on almost all the cells originating from the mesenchyme and mediate many biologic events, such as migration of vascular smooth muscle cells (SMCs), adhesion of osteoclasts to the bone matrix and angiogenesis. $\alpha v$ integrins are known to bind different ligands, including vitronectin, FN, osteopontin, fibrinogen and vWF, by interacting with the RGD motif [52]. Interestingly, EPC adhesion to denuded vessels appears to be also mediated by $\alpha v \beta 3$ - and $\alpha v \beta 5$-integrins, since inhibition of $\alpha v \beta 3$ - and $\alpha v \beta 5$-integrins with cyclic RGD peptides blocks EPC-mediated re-endothelialization of denuded arteries [88]. In agreement, integrin $\alpha v \beta 5$ has been described as essential to the adhesion of EPCs to differentiated endothelial cells [89].

\section{Integrin-mediated endothelial progenitor cells transendothelial migration}

Once EPCs adhere at specific homing sites they need to migrate through the endothelial monolayer and invade the underlying tissue. Concerning EPCs, very little is known in relation to integrins mediating transendothelial migration. In human adult PB-derived EPCs, transendothelial migration appears to be mediated mainly by $\beta 2$ integrins and depends on MCP-1 and VEGF [90]. This is further supported by a study showing that increased expression of ICAM-1 in ECs, via Akt activation, increases EPC homing and transendothelial migration in in vitro assays [91].

\section{Integrin-mediated endothelial progenitor cell invasion and migration}

As EPCs cross the endothelial monolayer, they need to migrate through the blood vessel basement membrane and through the interstitial ECM in order to arrive at the specific niches where they can exert their functions. These processes require multiple cell-ECM interactions and depend mainly on the integrin-ECM interactions and on extracellular proteases-ECM interactions. The essential role of the ECM as a provider of biochemical and biophysical cues that regulate EPCs cellular behavior is addressed in a recent report by Hanjaya-Putra $e t$ al., where the authors show that the ECM stiffness modulates EPC invasion. In detail, EPCs can sense matrix stiffness through signaling cascades downstream of integrin ligation leading to the activation of the Rho guanosine triphosphate hydrolase, cell division control protein 42 homolog. Accordingly, if the matrix stiffness is high, EPCs upregulate the production of extracellular proteases that allow both matrix degradation and EPC migration [92]. This study revealed that both integrins and extracellular proteases are essential to modulate EPC invasion and migration along the ECM. The contribution of integrins to EPC invasion and migration is further supported by Wijelath et al. These authors show 
that integrin $\alpha 5 \beta 1$ mediates EPC migration on FN towards a VEGF gradient, in vitro [44]. In another study, integrin $\alpha 6 \beta 1$ is described as an essential integrin regulating EPC adhesion and migration towards VEGF, in a phosphatidylinositol 3-kinase/Akt pathway dependent way. Furthermore, the same authors show that $\alpha 6 \beta 1$ integrin mediates EPC invasion and consequent tube formation in vitro and in vivo, being essential for EPC-mediated collateral vessel formation in ischemic hind limb mouse models $[56,87]$.

\section{Role of integrin-endothelial progenitor cell interactions on endothelial progenitor cell differentiation}

The functional activity of EPCs depends mainly on two interdependent processes: differentiation into mature ECs and direct incorporation into neovessels and/or production of paracrine and/or juxtacrine signals that promote interactions with pre-existing ECs and other cell types. Concerning EPC differentiation into EC, a study by our laboratory has shed some light onto the molecular pathways that modulate the different steps of EPC differentiation. We defined a global gene-expression profile of cord blood-EPC (CD133+, CD34+ and kinase insert domain receptor + ) during the process of endothelial differentiation in vitro. The gene profile data of EPC differentiation reveals a strict temporal regulation of endothelial differentiation, which can be divided into three sequential and distinct stages: integrinmediated adhesion to specific ECM components; growth factor-induced proliferation and survival; and maturation and functional acquisition of EC properties [43].

EPC adhesion to the ECM is an essential step during differentiation, allowing cells to attach onto a substrate and to acquire proliferative and survival signals from the underlying matrix. Moreover, direct interaction between integrins and ECM can regulate EPC paracrine factor production. Interestingly, the integrin expression profile in EPCs is variable throughout endothelial differentiation, further suggesting that integrin-ECM interactions can mediate different aspects of the endothelial differentiation process. In detail, integrin $\alpha 9$ is only expressed in undifferentiated EPCs (day 0 of differentiation), while $\beta 5$ and $\beta 7$ are only expressed in differentiating EPCs (day 13). On the other hand, integrin subunits $\alpha 4, \alpha 5$ and $\alpha \mathrm{v}$ are expressed throughout EPC differentiation. All the non-variable integrin subunits are FN-binding integrins, further pointing out that direct interaction of EPCs with FN is essential during endothelial differentiation. In fact, FN has been shown to be essential for vasculogenesis during embryonic development, as well as its receptor integrin $\alpha 5 \beta 1$. Accordingly, genes for FN and integrin subunit $\alpha 5$ are among the 12 genes considered critical for vasculogenesis since knockout mice for these genes are embryonic lethal with major vascular defects [93-95]. Concerning EPCs, early work by Asahara et al. revealed for the first time that these cells show higher adhesion and endothelial differentiation when plated on FN compared to collagen [6]. More recently, the role of the $\mathrm{FN}$-integrin $\alpha 5 \beta 1$ interaction in EPC differentiation has been addressed. FN is described as a major regulator of EPC differentiation since it promotes VEGF-induced differentiation of EPCs into ECs via specific binding to integrin $\alpha 5 \beta$ [44]. Although the precise mechanism by which FN and VEGF synergy regulates EPC differentiation is not clear, it is possible that the formation of FN/VEGF complexes by direct interactions of VEGF with FN heparin-II domain [96] leads firstly to the physical association between VEGFR-2 and $\alpha 5 \beta 1$ [97] and consequently to the activation of downstream pathways that may potentiate EPC endothelial differentiation.

The contribution of integrin-ECM interactions in EPC differentiation is further demonstrated in a recent study showing that vascular endothelial growth inhibitor, a known anti-angiogenic cytokine, impairs EPC adhesion and differentiation on both FN and vitronectin by downregulating the expression of integrin subunits $\alpha 5$ and $\alpha \mathrm{v}$, further suggesting the importance of both integrins during EPC differentiation [98]. Besides differentiating into ECs, EPCs can produce multiple paracrine factors that in turn can act on other cell types influencing multiple cellular processes. Interestingly, there is some data suggesting that integrin-ECM interactions can influence EPC paracrine factor production. For instance, integrin $\beta 5$ regulates EPCs paracrine factor production. Overexpression of integrin $\beta 5$ in EPCs results in integrin $\alpha \mathrm{v} \beta 5$ phosphorylation, activation of proto-oncogene tyrosineprotein kinase and activation of transcription factor STAT3, which in turn induce expression of the proangiogenic factors IL-8 and MCP-1 [99].

Recent investigation by Barsotti et al. shows that EPCs plated on different matrices produce different amounts of paracrine factors. For instance, when plated on fibrin, EPCs expressed increased levels of multiple cytokines, namely IL-16, platelet derived growth factor-BB, SDF-1, hepatocyte growth factor (HGF), Interferon gammainduced protein 10 (IP-10) and monokine induced by gamma interferon (MIG). This furthers suggests that the paracrine factor production by EPCs is also regulated by the integrin-ECM interactions [100]. Additionally, recent data collected from our group also suggests that EPCs grown on different ECM components produce different levels of paracrine factors. We observed that EPCs grown or gelatin, FN or on fibrin proteolytic fragment $\mathrm{E}$ (FbnE) express different levels of multiple paracrine factors. They showed higher expression of VEGF-A, transforming growth factor $\beta 1$, SDF-1, IL-8 and macrophage inflammatory protein- $1 \alpha$, however the precise mechanism 
downstream of the interaction between integrin $\alpha 5 \beta 1$ and $\mathrm{FbnE}$ was not established [54].

Endothelial progenitor cells as therapeutic agents - how to improve endothelial progenitor cell function in vivo: extracellular matrix scaffolds

Since EPCs where first isolated, many in vitro and in vivo preclinical studies have created great expectation for their wide use in clinical practice. In fact, to date, a dozen of complete interventional clinical trials concerning the application of $\mathrm{PB}$ or BM-derived EPCs in cardiovascular diseases have been published (Table 2) while many others are ongoing [111]. Despite the success of the application of EPCs as therapeutic agents in cardiovascular disease, there are some limitations to the interpretation of these clinical trials - namely the lack of

Table 2 Published interventional clinical trials using endothelial progenitor cells.

\begin{tabular}{|c|c|c|c|c|c|}
\hline Disease & $\begin{array}{l}\text { Patient } \\
\text { numbers }\end{array}$ & Intervention & Description & Results & Reference \\
\hline $\begin{array}{l}\text { Chronic } \\
\text { ischemic } \\
\text { heart } \\
\text { disease }\end{array}$ & 121 & $\begin{array}{l}\text { Transcoronary transplantation } \\
\text { of bone marrow-derived } \\
\text { progenitor cells }\end{array}$ & $\begin{array}{l}\text { Intracoronary infusion in patients } \\
\text { with chronic ischemic heart disease }\end{array}$ & $\begin{array}{l}\text { Reduced serum levels of heart failure } \\
\text { markers; } \\
\text { reduced mortality }\end{array}$ & {$[101]$} \\
\hline $\begin{array}{l}\text { Idiopathic } \\
\text { pulmonary } \\
\text { arterial } \\
\text { hypertension }\end{array}$ & 33 & $\begin{array}{l}\text { Transplantation of } \\
\text { autologous EPCs } \\
\text { (differentiated from } \\
\text { peripheral blood } \\
\text { mononuclear cells) }\end{array}$ & $\begin{array}{l}\text { Test safety, feasibility, and initial } \\
\text { clinical outcome of intravenous } \\
\text { infusion of autologous EPCs in } \\
\text { patients with idiopathic pulmonary } \\
\text { arterial hypertension }\end{array}$ & $\begin{array}{l}\text { Feasible and safe infusion of } \\
\text { autologous EPCs is beneficial to } \\
\text { exercise capacity and pulmonary } \\
\text { hemodynamics in patients with } \\
\text { idiopathic pulmonary arterial } \\
\text { hypertension }\end{array}$ & {$[102]$} \\
\hline $\begin{array}{l}\text { Chronic } \\
\text { ischemic } \\
\text { heart } \\
\text { disease }\end{array}$ & 75 & $\begin{array}{l}\text { Intracoronary infusion of } \\
\text { peripheral blood-EPCs and } \\
\text { bone marrow-derived } \\
\text { progenitor cells }\end{array}$ & $\begin{array}{l}\text { Effect of intracoronary EPC infusion } \\
\text { on the left ventricular contractile } \\
\text { function }\end{array}$ & $\begin{array}{l}\text { Feasible and safe transplantation of } \\
\text { bone marrow-derived progenitor cells } \\
\text { is associated with moderate but } \\
\text { significant improvement in the left } \\
\text { ventricular ejection fraction after three } \\
\text { months }\end{array}$ & {$[103]$} \\
\hline $\begin{array}{l}\text { Acute } \\
\text { myocardial } \\
\text { infarction }\end{array}$ & 26 & $\begin{array}{l}\text { Intracoronary injection of } \\
\text { EPCs (differentiated from } \\
\text { peripheral blood } \\
\text { mononuclear cells) }\end{array}$ & $\begin{array}{l}\text { Effect of intracoronary EPC infusion } \\
\text { on coronary vasomotion and left } \\
\text { ventricular function in patients after } \\
\text { recanalization of chronic coronary } \\
\text { total occlusion }\end{array}$ & $\begin{array}{l}\text { Increased left ventricular ejection } \\
\text { fraction, coronary flow reserve; } \\
\text { reduction in infarct size }\end{array}$ & {$[104]$} \\
\hline $\begin{array}{l}\text { Acute } \\
\text { myocardial } \\
\text { infarction }\end{array}$ & 11 & $\begin{array}{l}\text { Transcoronary transplantation } \\
\text { of bone marrow-derived } \\
\text { EPCs and mesenchymal stem } \\
\text { cells }\end{array}$ & $\begin{array}{l}\text { Effect of transcoronary } \\
\text { transplantation of EPCs and } \\
\text { mesenchymal stem cells on } \\
\text { myocardial contractility and tissue } \\
\text { regeneration }\end{array}$ & Reduction in infarct size & {$[105]$} \\
\hline $\begin{array}{l}\text { Acute } \\
\text { myocardial } \\
\text { infarction }\end{array}$ & 59 & $\begin{array}{l}\text { Intracoronary infusion of } \\
\text { peripheral blood EPCs and } \\
\text { bone marrow-derived } \\
\text { progenitor cells }\end{array}$ & $\begin{array}{l}\text { Effect of intracoronary EPC infusion } \\
\text { on left ventricular function, infarct } \\
\text { size and reactive hypertrophy }\end{array}$ & $\begin{array}{l}\text { Increased left ventricular ejection } \\
\text { fraction, no reactive hypertrophy; } \\
\text { Reduction in infarct size }\end{array}$ & {$[106]$} \\
\hline $\begin{array}{l}\text { Critical limb } \\
\text { ischemia }\end{array}$ & 28 & $\begin{array}{l}\text { Intramuscular injections of } \\
\text { peripheral blood granulocyte } \\
\text { colony stimulating factor } \\
\text { mobilized CD34+ CD133+ } \\
\text { EPCs }\end{array}$ & $\begin{array}{l}\text { Effect of intramuscular infusion on } \\
\text { and limb salvage rate for amputation } \\
\text { at } 12 \text { months }\end{array}$ & $\begin{array}{l}\text { Implantation of EPCs in critical limb } \\
\text { ischemia is a safe alternative, improves } \\
\text { tissue perfusion, and obtains high } \\
\text { amputation-free rates }\end{array}$ & {$[107]$} \\
\hline $\begin{array}{l}\text { Acute } \\
\text { myocardial } \\
\text { infarction }\end{array}$ & 366 & EPC capture stent & $\begin{array}{l}\text { Safety and efficacy of EPC capture } \\
\text { stents in the acute myocardial } \\
\text { infarction settings }\end{array}$ & $\begin{array}{l}\text { EPC stent is safe; } \\
\text { At two-year follow-up, the EPC group } \\
\text { showed favorable target vessel } \\
\text { revascularizations rate and stent } \\
\text { thrombosis remained a low-event } \\
\text { occurrence }\end{array}$ & [108] \\
\hline $\begin{array}{l}\text { ST elevation } \\
\text { acute } \\
\text { myocardial } \\
\text { infarction }\end{array}$ & 100 & EPC capture stent & $\begin{array}{l}\text { Safety and efficacy of EPC capture } \\
\text { stents in the ST elevation acute } \\
\text { myocardial infarction settings }\end{array}$ & $\begin{array}{l}\text { The study does not support the use of } \\
\text { EPC capture stents with short duration } \\
\text { dual antiplatelet therapy in patients } \\
\text { with ST elevation acute myocardial } \\
\text { infarction }\end{array}$ & [109] \\
\hline $\begin{array}{l}\text { Refractory } \\
\text { angina }\end{array}$ & 167 & $\begin{array}{l}\text { Intramyocardial injections of } \\
\text { autologous CD34+ cells }\end{array}$ & $\begin{array}{l}\text { Effect of intramyocardial injections of } \\
\text { autologous CD34+ cells on refractory } \\
\text { angina patient }\end{array}$ & $\begin{array}{l}\text { Intramyocardial injections of } \\
\text { autologous CD34+ cells improves } \\
\text { angina frequency and exercise } \\
\text { tolerance }\end{array}$ & {$[110]$} \\
\hline
\end{tabular}


appropriate controls, randomization and blinding. Other limitations are the use of distinct EPC populations, routes of delivery used and timing of cell delivery, all variables rendering cross-sectional comparison difficult [111]. Concerning the routes of delivery, studies have shown that the therapeutic capabilities of EPCs upon in vivo systemic transplantation were insignificant, because of their poor bio-distribution and low cell survival $[112,113]$. To avoid these drawbacks, several studies have attempted to inoculate EPCs directly at sites of vascular repair and healing, including infracted areas of the heart. Compared to systemic injection, this approach led to significantly greater, but still marginal, numbers of injected cells that survive in the infarct area and eventually contribute to tissue regeneration [114]. To overcome these limitations of conventional transplantation methods, there has been intense development of scaffolds that promote in situ cell retention and avoid non-specific cell homing. Considering the essential role of integrin-ECM interactions in EPC biology there has been a major effort to develop scaffolds constituted by biologically or artificially derived ECM that provide EPCs with ECM survival and proliferative and differentiating signals, rendering EPC in vivo application more efficient.

Biological scaffolds are composed of naturally occurring polymers present in the ECM, namely proteins and polysaccharides. The main proteins used for scaffold composition are collagens, fibrin and gelatin. Collagen matrices have been shown to support EPC differentiation and vessel formation. According to a study by Critser et al., EPCs vascularize collagen-based matrices in vivo although increasing collagen concentration significantly decreased EPC-derived vessels density but significantly increased vessel lumen sizes, suggesting that the physical properties of collagen matrices influence EPC vasculogenesis in vivo [115]. A more recent study described the differentiation of progenitor cells into ECs in a collagen matrix. This study showed that collagen protects progenitor cells from apoptosis and increases adhesion and invasion in an extracellular signal-regulated kinase pathway-dependent way [116].

Fibrin is also involved in the regulation of EPC biology. According to a recent study by Barsotti et al., when plated on fibrin, EPCs can adhere and differentiate into ECs to levels comparable to those obtained on FN, and they also show enhanced cell viability and cytokine production [100]. In another study, EPC exhibited biological activity after in vivo subcutaneous implantation in a fibrin matrix. Once in the fibrin matrix, EPCs migrate, differentiate into ECs and integrate into newly formed blood vessels [117]. Recent data from our laboratory further suggests that FbnE plays an essential role in EPC biology. We showed that FbnE potentiates the vasculogenic properties of EPCs and also promotes paracrine factor production. Moreover we observed that administration of a FbnE-enriched scaffold together with EPCs into mouse cutaneous wounds increases wound vascularization and consequent healing [54].

Artificial matrices include a group of scaffolds that mimic the ECM. These scaffolds combine biodegradable and biocompatible scaffolds with small synthetic peptides that mimic the integrin-binding sites of ECM molecules. Examples are synthetic mimics of FN (RGD and PHSRN) [118], laminin (Tyr-Ile-Gly-Ser-Arg motif and Ile-Lys-Val-Ala-Val motif) [119], or collagens (type I, Asp-Gly-Glu-Ala motif; type IV, Thr-Ala-Gly-Ser-CysLeu-Arg-Lis-Phe-Ser-Thr-Met motif) [120,121]. The FNmimics RGD and PHSRN have both been implicated in the differentiation of cells toward the endothelial lineage [122]. A recent work by Alobaid et a.l showed an enhanced attachment and increased endothelial outgrowth when EPCs were cultured on RGD-coated well plates [123], while Ferreira et al. reported a 20-fold increase in EC differentiation from embryonic stem cells when these cells were encapsulated in a dextran-based hydrogel containing the RGD peptide [118].

The use of scaffolds mimicking the ECM in physiological processes was addressed by different investigators. Blindt and colleagues investigated this concept by incorporating integrin-binding cyclic RGD (cRGD) peptide with $\alpha_{\mathrm{v}} \beta_{3}$-integrin-binding capacities into a newly designed polymer stent-coating. This stent was analyzed in in vitro and in vivo porcine models for its potential to recruit and bind EPCs and limit coronary neointimal formation. In vitro, the cRGD peptide stimulated the outgrowth, shear-resistant recruitment and migration of EPCs. In vivo, 12 weeks after implantation, both mean neointimal area and mean percent area stenosis were significantly reduced in CRGD peptide-loaded polymer stents by accelerated stent endothelialization compared with the control stents [124]. In another study, Kim et al. described that targeted delivery of EPCs using an RGD-g-poly-L-lactic acid scaffold enhances dermal wound closure and vascularization in mouse models of wound healing. EPCs grown on RGD-g-poly-L-lactic acid scaffolds show increased proliferation, endothelial differentiation and consequent incorporation on wound vessels [125]. Together, these different approaches suggest targeted manipulation of ECM and/or integrin (adhesion) at vascular repair and formation sites may improve EPC function and thereby improve the neovascularization processes.

\section{Conclusions}

There has been great interest in manipulating EPCs for neovascularization purposes, namely in the context of tissue regeneration and vascular repair. As is certainly 


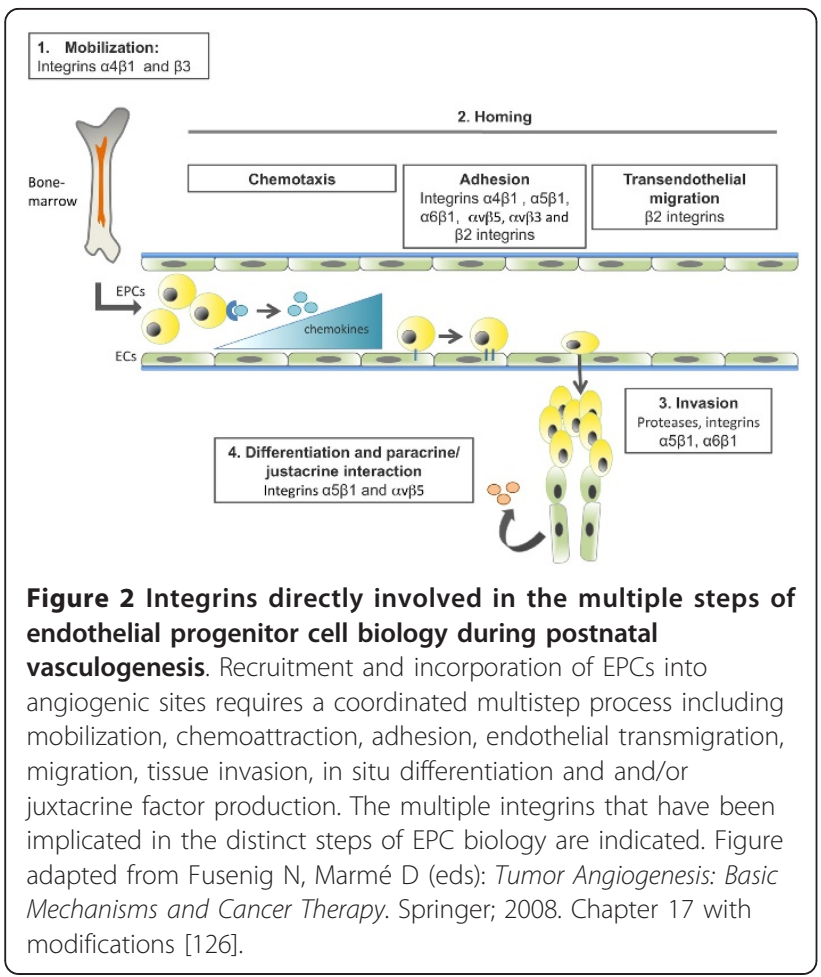

clear from the abundant body of literature cited in this review, integrins play a crucial role in modulating several aspects of EPC biology and function (Figure 2). Therefore, although there has been some success in using EPCs as therapeutic agents (as shown by recent clinical trials), we suggest that targeted and tissue-specific manipulation of EPC-integrin interactions may be crucial to further improve the usage of this cell population as a relevant clinical agent.

\begin{abstract}
Abbreviations
Akt: protein kinase B; BM: bone marrow; CD: cluster of differentiation; CXCR4: CXC chemokine receptor type 4; EC: endothelial cell; ECM: extracellular matrix; EPC: endothelial progenitor cell; FN: fibronectin; FbnE: fibrin proteolytic fragment E; ICAM-1/2: inter-cellular adhesion molecule 1/2; IL: interleukin; MCP-1: monocyte chemotactic protein 1; MMP: matrix metalloproteinase; PB: peripheral blood; PHSRN: proline-histidine-serinearginine-aspartine motif; RGD: arginine-glycine-aspartate motif; SDF-1: stromal derived factor 1; VCAM-1: vascular cell adhesion 1; VEGF: vascular endothelial growth factor; VEGFR: vascular endothelial growth factor receptor; vWF: von Willebrand factor.
\end{abstract}

\section{Author details}

${ }^{1}$ Angiogenesis Laboratory, CIPM, Instituto Português de Oncologia Francisco Gentil, EPE, Lisboa, Portugal. ${ }^{2}$ Instituto Gulbenkian Ciencia, Oeiras, Portugal. ${ }^{3}$ CEDOC, Faculdade de Ciências Médicas, Lisbon, Portugal.

\section{Authors' contributions}

Both authors contributed equally to the conception of the manuscript. Both authors read and approved the final manuscript.

\section{Competing interests}

The authors declare that they have no competing interests.
Received: 14 December 2011 Accepted: 12 March 2012

Published: 12 March 2012

\section{References}

1. Carmeliet P: Angiogenesis in health and disease. Nat Med 2003, 9:653-660.

2. Patan S: Vasculogenesis and angiogenesis as mechanisms of vascular network formation, growth and remodeling. I Neurooncol 2000, 50:1-15.

3. Hueper WC, Russel MA: Capillary-like formations in tissue culture of leukocytes. Arch Exp Zellforsch 1932, 12:407-424.

4. Parker RC: The development of organized vessels in cultures of blood cells. Science 1933, 2005:544-546.

5. White JF, Parshley MS: Growth in vitro of blood vessels from bone marrow of adult chickens. Am J Anat 1951, 89:321-345.

6. Asahara T, Murohara T, Sullivan A, Silver M, van der Zee R, Li T, Witzenbichler B, Schatteman G, Isner JM: Isolation of putative progenitor endothelial cells for angiogenesis. Science 1997, 275:964-966.

7. Shi Q, Rafii S, Wu MH, Wijelath ES, Yu C, Ishida A, Fujita Y, Kothari S, Mohle R, Sauvage LR, Moore MA, Storb RF, Hammond WP: Evidence for circulating bone marrow-derived endothelial cells. Blood 1998, 92:362-367.

8. Peichev M, Naiyer AJ, Pereira D, Zhu Z, Lane WJ, Williams M, Oz MC, Hicklin DJ, Witte L, Moore MA, Rafii S: Expression of VEGFR-2 and AC133 by circulating human CD34+ cells identifies a population of functional endothelial precursors. Blood 2000, 95:952-958.

9. Asahara T, Masuda H, Takahashi T, Kalka C, Pastore C, Silver M, Kearne M, Magner M, Isner JM: Bone marrow origin of endothelial progenitor cells responsible for postnatal vasculogenesis in physiological and pathological neovascularization. Circ Res 1999, 85:221-228.

10. Young PP, Hofling AA, Sands MS: VEGF increases engraftment of bone marrow-derived endothelial progenitor cells (EPCs) into vasculature of newborn murine recipients. PNAS 2002, 99:11951-11956.

11. Vaughan EE, Liew A, Mashayekhi K, Dockery P, McDermott J, Kealy B, Flynn A, Duffy A, O'Regan CC, Barry FP, O'Brien T: Pre-treatment of endothelial progenitor cells with osteopontin enhances cell therapy for peripheral vascular disease. Cell Transplant 2012.

12. Kalka C, Masuda H, Takahashi T, Kalka-Moll WM, Silver M, Kearney M, Li T, Isner JM, Asahara T: Transplantation of ex vivo expanded endothelial progenitor cells for therapeutic neovascularization. PNAS 2000, 97:3422-3427.

13. Kocher AA, Schuster MD, Szabolcs MJ, Takuma S, Burkhoff D, Wang J, Homma S, Edwards NM, Itescu S: Neovascularization of ischemic myocardium by human bone-marrow-derived angioblasts prevents cardiomyocyte apoptosis, reduces remodeling and improves cardiac function. Nat Med 2001, 7:430-436.

14. Fan Y, Shen F, Frenzel T, Zhu W, Ye J, Liu J, Chen Y, Su H, Young WL, Yang GY: Endothelial progenitor cell transplantation improves long-term stroke outcome in mice. Ann Neurol 2010, 67(4):488-497.

15. Otani A, Kinder K, Ewalt K, Otero FJ, Schimmel P, Friedlander M: Bone marrow-derived stem cells target retinal astrocytes and can promote or inhibit retinal angiogenesis. Nat Med 2002, 8:1004-1010.

16. Mathews V, Hanson PT, Ford E, Fujita J, Polonsky KS, Graubert TA: Recruitment of bone marrow-derived endothelial cells to sites of pancreatic beta-cell injury. Diabetes 2004, 53:91-98.

17. Bauer SM, Goldstein L, Bauer RJ, Chen H, Putt M, Velazquez OC: The bone marrow-derived endothelial progenitor cell response is impaired in delayed wound healing from ischemia. J Vasc Surg 2006, 43:134-141.

18. Nakamura T, Torimura T, Sakamoto M, Hashimoto O, Taniguchi E, Inoue K, Sakata R, Kumashiro R, Murohara T, Ueno T, Sata M: Significance and therapeutic potential of endothelial progenitor cell transplantation in a cirrhotic liver rat model. Gastroenterology 2007, 133:91-107.

19. Liu X, Li Y, Liu Y, Luo Y, Wang D, Annex BH, Goldschmidt-Clermont PJ: Endothelial progenitor cells (EPCs) mobilized and activated by neurotrophic factors may contribute to pathologic neovascularization in diabetic retinopathy. Am J Pathol 2010, 176:504-515.

20. Torsney E, Mandal K, Halliday A, Jahangiri M, Xu Q: Characterization of progenitor cells in human atherosclerotic vessels. Atherosclerosis 2007, 191:259-264

21. Lyden D, Hattori K, Dias S, Costa C, Blaikie P, Butros L, Chadburn A, Heissig B, Marks W, Witte L, Wu Y, Hicklin D, Zhu Z, Hackett NR, Crystal RG, Moore MA, Hajjar KA, Manova K, Benezra R, Rafii S: Impaired recruitment of 
bone-marrow-derived endothelial and hematopoietic precursor cells blocks tumor angiogenesis and growth. Nat Med 2001, 7:1194-1201.

22. Li H, Gerald WL, Benezra R: Utilization of bone marrow-derived endothelial cell precursors in spontaneous prostate tumors varies with tumor grade. Cancer Res 2004, 64:6137-6143.

23. Duda DG, Cohen KS, Kozin SV, Perentes JY, Fukumura D, Scadden DT, Jain RK: Evidence for incorporation of bone marrow-derived endothelial cells into perfused blood vessels in tumors. Blood 2006, 107:2774-2776.

24. Gao D, Nolan DJ, Mellick AS, Bambino K, McDonnell K, Mittal V: Endothelial progenitor cells control the angiogenic switch in mouse lung metastasis. Science 2008, 319:195-198.

25. Rafii S, Lyden D: Therapeutic stem and progenitor cell transplantation for organ vascularization and regeneration. Nat Med 2003, 9:702-712.

26. Urbich C, Dimmeler S: Endothelial progenitor cells: functional characterization. Trends Cardiovascr Med 2004, 14:318-322.

27. Timmermans F, Plum J, Yöder MC, Ingram DA, Vandekerckhove B, Case J: Endothelial progenitor cells: identity defined? J Cell Mol Med 2009, 13:87-102

28. Urbich C, Dimmeler S: Endothelial progenitor cells: characterization and role in vascular biology. Circ Res 2004, 95:343-353.

29. Harrison JS, Rameshwar P, Chang V, Bandari P: Oxygen saturation in the bone marrow of healthy volunteers. Blood 2002, 99:394

30. Ceradini DJ, Kulkarni AR, Callaghan MJ, Tepper OM, Bastidas N, Kleinman ME, Capla JM, Galiano RD, Levine JP, Gurtner GC: Progenitor cell trafficking is regulated by hypoxic gradients through HIF-1 induction of SDF-1. Nat Med 2004, 10:858-864.

31. Dimmeler S, Fleming I, Fisslthaler B, Hermann C, Busse R, Zeiher AM: Activation of nitric oxide synthase in endothelial cells by Akt-dependent phosphorylation. Nature 1999, 399:601-605.

32. Aicher A, Heeschen C, Mildner-Rihm C, Urbich C, Ihling C, Technau-lhling K, Zeiher AM, Dimmeler S: Essential role of endothelial nitric oxide synthase for mobilization of stem and progenitor cells. Nat Med 2003, 9:1370-1376.

33. Heissig B, Hattori K, Dias S, Friedrich M, Ferris B, Hackett NR, Crystal RG, Besmer P, Lyden D, Moore MA, Werb Z, Rafii S: Recruitment of stem and progenitor cells from the bone marrow niche requires MMP-9 mediated release of kit-ligand. Cell 2002, 109:625-637.

34. Yamaguchi J, Kusano KF, Masuo O, Kawamoto A, Silver M, Murasawa S, Bosch-Marce M, Masuda H, Losordo DW, Isner JM, Asahara T: Stromal cellderived factor-1 effects on ex vivo expanded endothelial progenitor cell recruitment for ischemic neovascularization. Circulation 2003, 107:1322-1328

35. De Falco E, Porcelli $D$, Torella AR, Straino S, lachininoto MG, Orlandi A, Truffa S, Biglioli P, Napolitano M, Capogrossi MC, Pesce M: SDF-1 involvement in endothelial phenotype and ischemia-induced recruitment of bone marrow progenitor cells. Blood 2004, 104:3472-3482.

36. Chen L, Wu F, Xia WH, Zhang YY, Xu SY, Cheng F, Liu X, Zhang XY, Wang SM, Tao J: CXCR4 gene transfer contributes to in vivo reendothelialization capacity of endothelial progenitor cells. Cardiovas Res 2004, 88:462-470.

37. Kocher AA, Schuster MD, Bonaros N, Lietz K, Xiang G, Martens TP, Kurlansky PA, Sondermeijer H, Witkowski P, Boyle A, Homma S, Wang SF, Itescu S: Myocardial homing and neovascularization by human bone marrow angioblasts is regulated by IL-8/Gro CXC chemokines. J Mol Cell Cardiol 2006, 40:455-464.

38. Spring H, Schüler T, Arnold B, Hämmerling GJ, Ganss R: Chemokines direct endothelial progenitors into tumor neovessels. PNAS 2005, 102:18111-18116.

39. Jones CP, Pitchford SC, Lloyd CM, Rankin SM: CXCR2 mediates the recruitment of endothelial progenitor cells during allergic airways remodeling. Stem Cells 2009, 27:3074-3081.

40. Huang PH, Chen YH, Wang CH, Chen JS, Tsai HY, Lin FY, Lo WY, Wu TC, Sata M, Chen JW, Lin SJ: Matrix metalloproteinase-9 is essential for ischemia-induced neovascularization by modulating bone marrowderived endothelial progenitor cells. Arterioscler Thromb Vasc Bio 2009, 29:1179-1184.

41. Urbich C, Heeschen C, Aicher A, Sasaki K, Bruhl T, Farhadi MR, Vajkoczy P, Hofmann WK, Peters C, Pennacchio LA, Abolmaali ND, Chavakis E, Reinheckel T, Zeiher AM, Dimmeler S: Cathepsin L is required for endothelial progenitor cell-induced neovascularization. Nat Med 2005, 11:206-213.
42. Basire A, Sabatier F, Ravet S, Lamy E, Mialhe A, Zabouo G, Paul P, Gurewich V, Sampol J, Dignat-George F: High urokinase expression contributes to the angiogenic properties of endothelial cells derived from circulating progenitors. Thromb Haemost 2006, 95:678-688.

43. Igreja C, Fragoso R, Caiado F, Clode N, Henriques A, Camargo L, Reis EM Dias S: Detailed molecular characterization of cord blood-derived endothelial progenitors. Exp Hematol 2008, 36:193-203.

44. Wijelath ES, Rahman S, Murray J, Patel Y, Savidge G, Sobel M: Fibronectin promotes VEGF-induced CD34+ cell differentiation into endothelial cells. J Vasc Surg 2004, 39:655-660.

45. Hildbrand P, Cirulli V, Prinsen RC, Smith KA, Torbett BE, Salomon DR, Crisa L: The role of angiopoietins in the development of endothelial cells from cord blood CD34+ progenitors. Blood 2004, 104:2010-2019.

46. Rössig L, Urbich C, Brühl T, Dernbach E, Heeschen C, Chavakis E, Sasaki K, Aicher D, Diehl F, Seeger F, Potente M, Aicher A, Zanetta L, Dejana E, Zeiher AM, Dimmeler S: Histone deacetylase activity is essential for the expression of HoxA9 and for endothelial commitment of progenitor cells. J Exp Med 2005, 201:1825-1835.

47. Urbich C, Aicher A, Heeschen C, Dernbach E, Hofmann WK, Zeiher AM, Dimmeler S: Soluble factors released by endothelial progenitor cells promote migration of endothelial cells and cardiac resident progenitor cells. J Mol Cell Cardiol 2005, 39:733-742.

48. Suh W, Kim KL, Kim JM, Shin IS, Lee YS, Lee JY, Jang HS, Lee JS, Byun J, Choi JH, Jeon ES, Kim DK: Transplantation of endothelial progenitor cells accelerates dermal wound healing with increased recruitment of monocytes/macrophages and neovascularization. Stem Cells 2005 23:571-1578.

49. Hynes RO: The extracellular matrix: not just pretty fibrils. Science 2009, 326:1216-1219.

50. Jarvelainen H, Sainio A, Koulu M, Wight TN, Penttinen R: Extracellular matrix molecules: potential targets in pharmacotherapy. Pharmacol Rev 2009, 61:198-223.

51. Schaefer L, Schaefer RM: Proteoglycans: from structural compounds to signaling molecules. Cell Tissue Res 2010, 339:237-246.

52. Hynes RO: Integrins: bidirectional, allosteric signaling machines. Cell 2002, 110:673-687.

53. Deb A, Skelding KA, Wang S, Reeder M, Simper D, Caplice NM: Integrin profile and in vivo homing of human smooth muscle progenitor cells. Circulation 2004, 110:2673-2677.

54. Caiado F, Carvalho T, Silva F, Castro C, Clode N, Dye JF, Dias S: The role of fibrin $\mathrm{E}$ on the modulation of endothelial progenitors adhesion, differentiation and angiogenic growth factor production and the promotion of wound healing. Biomaterials 2011, 32:7096-7105.

55. Caiado F, Real C, Carvalho T, Dias S: Notch pathway modulation on bone marrow-derived vascular precursor cells regulates their angiogenic and wound healing potential. PLos One 2008, 3:e3752.

56. Hibbert B, Ma X, Pourdjabbar A, Holm E, Rayner K, Chen YX, Sun J, Filion L, O'Brien ER: Inhibition of endothelial progenitor cell glycogen synthase kinase-3beta results in attenuated neointima formation and enhanced re-endothelialization after arterial injury. Cardiovasc Res 2009, 83:16-23.

57. Angelos MG, Brown MA, Satterwhite LL, Levering WW, Shaked NT, Truskey GA: Dynamic adhesion of umbilical cord blood endothelial progenitor cells under laminar shear stress. Biophys J 2010, 99:3545-3554

58. Bouvard C, Gafsou B, Dizier B, Galy-Fauroux I, Lokajczyk A, Boisson-Vidal C, Fischer AM, Helley D: Alpha6-integrin subunit plays a major role in the proangiogenic properties of endothelial progenitor cells. Arterioscler Thromb Vas Biol 2010, 30:1569-1575.

59. Walter DH, Rittig K, Bahlmann FH, Kirchmair R, Silver M, Murayama T, Nishimura H, Losordo DW, Asahara T, Isner JM: Statin therapy accelerates reendothelialization: a novel effect involving mobilization and incorporation of bone marrow-derived endothelial progenitor cells. Circulation 2002, 105:3017-3024.

60. Schroeter MR, Leifheit M, Sudholt P, Heida NM, Dellas C, Rohm I, Alves F, Zientkowska M, Rafail S, Puls M, Hasenfuss G, Konstantinides S, Schäfer K: Leptin enhances the recruitment of endothelial progenitor cells into neointimal lesions after vascular injury by promoting integrin-mediated adhesion. Circ Res 2008, 103:536-544.

61. Chavakis E, Aicher A, Heeschen C, Sasaki K, Kaiser R, El Makhfi N, Urbich C, Peters T, Scharffetter-Kochanek K, Zeiher AM, Chavakis T, Dimmeler S: Role of beta2-integrins for homing and neovascularization capacity of endothelial progenitor cells. J Exp Med 2005, 201:63-72. 
62. Kummer C, Ginsberg MH: New approaches to blockade of a4-integrins, proven therapeutic targets in chronic inflammation. Biochem Pharmacol 2006, 72:1460-1468.

63. Qin G, li M, Silver M, Wecker A, Bord E, Ma H, Gavin M, Goukassian DA, Yoon YS, Papayannopoulou T, Asahara T, Kearney M, Thorne T, Curry C, Eaton L, Heyd L, Dinesh D, Kishore R, Zhu Y, Losordo DW: Functional disruption of alpha4 integrin mobilizes bone marrow-derived endothelial progenitors and augments ischemic neovascularization. J Exp Med 2006, 203:153-163.

64. Butcher EC, Picker LJ: Lymphocyte homing and homeostasis. Science 1996, 272:60-62.

65. Springer TA: Traffic signals for lymphocyte recirculation and leukocyte emigration: the multistep paradigm. Cell 1994, 76:301-314

66. Chan BM, Elices MJ, Murphy E, Hemler ME: Adhesion to vascular cell adhesion molecule 1 and fibronectin. Comparison of alpha 4 beta 1 (VLA-4) and alpha 4 beta 7 on the human B cell line JY. J Biol Chem 1992, 267:8366-8370.

67. Rüegg C, Postigo AA, Sikorski EE, Butcher EC, Pytela R, Erle DJ: Role of integrin alpha 4 beta 7/alpha 4 beta $P$ in lymphocyte adherence to fibronectin and VCAM-1 and in homotypic cell clustering. J Cell Biol 1992, 117:179-189.

68. Berlin C, Berg EL, Briskin MJ, Andrew DP, Kilshaw PJ, Holzmann B, Weissman IL, Hamann A, Butcher EC: Alpha 4 beta 7 integrin mediates lymphocyte binding to the mucosal vascular addressin MAdCAM-1. Cell 1993, 74:185-195.

69. Watson AR, Pitchford SC, Reynolds LE, Direkze N, Brittan M, Alison MR, Rankin S, Wright NA, Hodivala-Dilke KM: Deficiency of bone marrow beta3-integrin enhances non-functional neovascularization. J Pathol 2010, 220:435-445

70. Vajkoczy P, Blum S, Lamparter M, Mailhammer R, Erber R, Engelhardt B, Vestweber D, Hatzopoulos AK: Multistep nature of microvascular recruitment of ex vivo-expanded embryonic endothelial progenitor cells during tumor angiogenesis. J Exp Med 2003, 197:1755-1765.

71. Harris ES, Mclntyre TM, Prescott SM, Zimmerman GA: The leukocyte integrins. J Biol Chem 2000, 275:23409-23412.

72. Jin H, Aiyer A, Su J, Borgstrom P, Stupack D, Friedlander M, Varner J: A homing mechanism for bone marrow-derived progenitor cell recruitment to the neovasculature J Clin Invest 2006, 116:652-662.

73. Orschell-Traycoff CM, Hiatt K, Dagher RN, Rice S, Yoder MC, Srour EF: Homing and engraftment potential of Sca-1+lin- cells fractionated on the basis of adhesion molecule expression and position in cell cycle. Blood 2000, 96:1380-1387

74. Carmona G, Chavakis E, Koehl U, Zeiher AM, Dimmeler S: Activation of Epac stimulates integrin-dependent homing of progenitor cells. Blood 2008, 111:2640-2646.

75. Pytela R, Pierschbacher MD, Ruoslahti E: Identification and isolation of a $140 \mathrm{kd}$ cell surface glycoprotein with properties expected of a fibronectin receptor. Cell 1985, 40:191-198.

76. Roman J, LaChance RM, Broekelmann TJ, Kennedy CJ, Wayner EA, Carter WG, McDonald JA: The fibronectin receptor is organized by extracellular matrix fibronectin: implications for oncogenic transformation and for cell recognition of fibronectin matrices. J Cell Biol 1989, 108:2529-2543

77. Akiyama SK, Yamada SS, Chen WT, Yamada KM: Analysis of fibronectin receptor function with monoclonal antibodies: roles in cell adhesion, migration, matrix assembly, and cytoskeletal organization. J Cell Biol 1989, 109:863-875

78. Giancotti FG, Ruoslahti E: Elevated levels of the alpha 5 beta 1 fibronectin receptor suppress the transformed phenotype of Chinese hamster ovary cells. Cell 1990, 60:849-859.

79. Werb Z, Tremble PM, Behrendtsen O, Crowley E, Damsky CH: Signal transduction through the fibronectin receptor induces collagenase and stromelysin gene expression. J Cell Biol 1989, 109:877-889.

80. Yang JT, Rayburn H, Hynes RO: Embryonic mesodermal defects in alpha 5 integrin-deficient mice. Development 1993, 119:1093-1105.

81. Bauters C, Marotte F, Hamon M, Oliviéro P, Farhadian F, Robert V, Samuel $J$, Rappaport $L$ : Accumulation of fetal fibronectin mRNAs after balloon denudation of rabbit arteries. Circulation 1995, 92.904-911.

82. Angelos MG, Brown MA, Satterwhite LL, Levering WW, Shaked NT, Truskey GA: Dynamic adhesion of umbilical cord blood endothelial progenitor cells under laminar shear stress. Biophys J 2010, 99:3545-3554
83. Wary KK, Vogel SM, Garrean S, Zhao YD, Malik AB: Requirement of alpha(4) beta(1) and alpha(5)beta(1) integrin expression in bone-marrow-derived progenitor cells in preventing endotoxin-induced lung vascular injury and edema in mice. Stem Cells 2009, 27:3112-3120.

84. Georges-Labouesse E, Messaddeg N, Yehia G, Cadalbert L, Dierich A, Le Meur M: Absence of integrin alpha 6 leads to epidermolysis bullosa and neonatal death in mice. Nat Genet 1996, 13:370-373.

85. Chabut D, Fischer AM, Colliec-Jouault S, Laurendeau I, Matou S, Le Bonniec B, Helley D: Low molecular weight fucoidan and heparin enhance the basic fibroblast growth factor-induced tube formation of endothelial cells through heparan sulfate-dependent alpha6 overexpression. Mol Pharmacol 2003, 64:696-702.

86. Qian H, Tryggvason K, Jacobsen SE, Ekblom M: Contribution of alpha6 integrins to hematopoietic stem and progenitor cell homing to bone marrow and collaboration with alpha4 integrins. Blood 2006, 107:3503-3510

87. Smadja DM, Bièche I, Helley D, Laurendeau I, Simonin G, Muller L, Aiach M, Gaussem P: Increased VEGFR2 expression during human late endothelial progenitor cells expansion enhances in vitro angiogenesis with upregulation of integrin alpha(6). J Cell Mol Med 2007, 11:1149-1161.

88. Kokubo T, Uchida H, Choi ET: Integrin alpha(v)beta(3) as a target in the prevention of neointimal hyperplasia. J Vasc Surg 2007, 45(Suppl A): A33-A38.

89. Di Santo S, Diehm N, Ortmann J, Völzmann J, Yang Z, Keo HH, Baumgartner I, Kalka C: Oxidized low density lipoprotein impairs endothelial progenitor cell function by downregulation of E-selectin and integrin alpha(v)beta5. Biochem Biophys Res Commun 2008, 373:528-532.

90. Chavakis E, Hain A, Vinci M, Carmona G, Bianchi ME, Vajkoczy P, Zeiher AM, Chavakis T, Dimmeler S: High-mobility group box 1 activates integrindependent homing of endothelial progenitor cells. Circ Res 2007, 100:204-212.

91. Hur J, Yoon CH, Lee CS, Kim TY, Oh IY, Park KW, Kim JH, Lee HS, Kang HJ, Chae $\mathrm{H}, \mathrm{O}$, BH, Park YB, Kim HS: Akt is a key modulator of endothelial progenitor cell trafficking in ischemic muscle. Stem Cells 2007, 25:1769-1778.

92. Hanjaya-Putra D, Yee J, Ceci D, Truitt R, Yee D, Gerecht S: Vascular endothelial growth factor and substrate mechanics regulate in vitro tubulogenesis of endothelial progenitor cells. J Cell Mol Med 2010, 14:2436-2447.

93. Yang JT, Rayburn H, Hynes RO: Embryonic mesodermal defects in alpha 5 integrin-deficient mice. Development 1993, 119:1093-1105.

94. George EL, Baldwin HS, Hynes RO: Fibronectins are essential for heart and blood vessel morphogenesis but are dispensable for initial specification of precursor cells. Blood 1997, 90:3073-3081

95. Goh KL, Yang JT, Hynes RO: Mesodermal defects and cranial neural crest apoptosis in alpha5 integrin-null embryos. Development 1997, 124:4309-4319.

96. Wijelath ES, Rahman S, Namekata M, Murray J, Nishimura T, MostafaviPour Z, Patel Y, Suda Y, Humphries MJ, Sobel M: Heparin-II domain of fibronectin is a vascular endothelial growth factor-binding domain: enhancement of VEGF biological activity by a singular growth factor/ matrix protein synergism. Circ Res 2006, 99:853-860.

97. Wijelath ES, Murray J, Rahman S, Patel Y, Ishida A, Strand K, Aziz S, Cardona C, Hammond WP, Savidge GF, Rafii S, Sobel M: Novel vascular endothelial growth factor binding domains of fibronectin enhance vascular endothelial growth factor biological activity. Circ Res 2002, 91:25-31.

98. Tian F, Liang PH, Li L-Y: Inhibition of endothelial progenitor cell differentiation by VEGI. Blood 2009, 113:5352-5360.

99. Leifheit-Nestler M, Conrad G, Heida NM, Limbourg A, Limbourg FP, Seidler T, Schroeter MR, Hasenfuss G, Konstantinides S, Schäfer K: Overexpression of integrin beta 5 enhances the paracrine properties of circulating angiogenic cells via Src kinase-mediated activation of STAT3. Arterioscler Thromb Vasc Biol 2010, 30:1398-1406.

100. Barsotti MC, Magera A, Armani C, Chiellini F, Felice F, Dinucci D, Piras AM, Minnocci A, Solaro R, Soldani G, Balbarini A, Di Stefano R: Fibrin acts as biomimetic niche inducing both differentiation and stem cell marker expression of early human endothelial progenitor cells. Cell Prolif 2011, 44:33-48.

101. Assmus B, Fischer-Rasokat U, Honold J, Seeger FH, Fichtlscherer S, Tonn T, Seifried E, Schächinger V, Dimmeler S, Zeiher AM: Transcoronary 
transplantation of functionally competent BMCs is associated with a decrease in natriuretic peptide serum levels and improved survival of patients with chronic postinfarction heart failure: results of the TOPCARE- CHD Registry. Circ Res 2007, 100:1234-1241.

102. Wang XX, Zhang FR, Shang YP, Zhu JH, Xie XD, Tao QM, Zhu JH, Chen JZ: Transplantation of autologous endothelial progenitor cells may be beneficial in patients with idiopathic pulmonary arterial hypertension: a pilot randomized controlled trial. J Am Coll Cardiol 2007, 49:1566-1571.

103. Assmus B, Honold J, Schächinger V, Britten MB, Fischer-Rasokat U, Lehmann R, Teupe C, Pistorius K, Martin H, Abolmaali ND, Tonn T, Dimmeler S, Zeiher AM: Transcoronary transplantation of progenitor cells after myocardial infarction. N Eng J Med 2006, 355:1222-1232.

104. Erbs S, Linke A, Adams V, Lenk K, Thiele H, Diederich KW, Emmrich F, Kluge R, Kendziorra K, Sabri O, Schuler G, Hambrecht R: Transplantation of blood-derived progenitor cells after recanalization of chronic coronary artery occlusion: first randomized and placebo-controlled study. Circ Res 2005, 97:756-762.

105. Katritsis DG, Sotiropoulou PA, Karvouni E, Karabinos I, Korovesis S, Perez SA, Voridis EM, Papamichail M: Transcoronary transplantation of autologous mesenchymal stem cells and endothelial progenitors into infarcted human myocardium. Cathet Cardiovasc Interv 2005, 65:321-329.

106. Schächinger V, Assmus B, Britten MB, Honold J, Lehmann R, Teupe C, Abolmaali ND, Vogl TJ, Hofmann WK, Martin H, Dimmeler S, Zeiher AM: Transplantation of progenitor cells and regeneration enhancement in acute myocardial infarction: final one-year results of the TOPCARE-AMI trial. J Am Coll Cardiol 2004, 44:1690-1699.

107. Lara-Hernandez R, Lozano-Vilardell P, Blanes P, Torreguitart-Mirada N, Galmés A, Besalduch J: Safety and efficacy of therapeutic angiogenesis as a novel treatment in patients with critical limb ischemia. Ann Vasc Surg 2010, 24:287-294.

108. Chong E, Poh KK, Liang S, Lee RC, Low A, Teo SG, Tan HC: Two-year clinical registry follow-up of endothelial progenitor cell capture stent versus sirolimus-eluting bioabsorbable polymer-coated stent versus bare metal stents in patients undergoing primary percutaneous coronary intervention for ST elevation myocardial infarction. J Interv Cardiol 2010, 23:101-108.

109. Bystroň $M$, Cervinka P, Spaček R, Kvašňák $M$, Jakabčin J, Cervinková $M$, Kala P, Widimský P: Randomized comparison of endothelial progenitor cells capture stent versus cobalt-chromium stent for treatment of stelevation myocardial infarction six-month clinical, angiographic and IVUS follow-up. Cathet Cardiovasc Interv 2010, 76:627-631.

110. Losordo DW, Henry TD, Davidson C, Sup Lee J, Costa MA, Bass T, Mendelsohn F, Fortuin FD, Pepine CJ, Traverse JH, Amrani D, Ewenstein BM, Riedel N, Story K, Barker K, Povsic TJ, Harrington RA, Schatz RA: Intramyocardial, autologous CD34+ cell therapy for refractory angina. Circ Res 2011, 109:428-436.

111. Napoli C, Hayashi T, Cacciatore F, Casamassimi A, Casini C, Al-Omran M, Ignarro LJ: Endothelial progenitor cells as therapeutic agents in the microcirculation: an update. Atherosclerosis 2011, 215:9-22.

112. Aicher A, Brenner W, Zuhayra M, Badorff C, Massoudi S, Assmus B, Eckey T, Henze E, Zeiher AM, Dimmeler S: Assessment of the tissue distribution of transplanted human endothelial progenitor cells by radioactive labeling. Circulation 2003, 107:2134-2139.

113. Müller-Ehmsen J, Krausgrill B, Burst V, Schenk K, Neisen UC, Fries JW Fleischmann BK, Hescheler J, Schwinger RH: Effective engraftment but poor mid-term persistence of mononuclear and mesenchymal bone marrow cells in acute and chronic rat myocardial infarction. $J \mathrm{Mol}$ Cell Cardiol 2006, 41:876-884

114. Bonaros N, Rauf R, Schachner T, Laufer G, Kocher A: Enhanced cell therapy for ischemic heart disease. Transplantation 2008, 86:1151-1160

115. Critser PJ, Kreger ST, Voytik-Harbin SL, Yoder MC: Collagen matrix physical properties modulate endothelial colony forming cell-derived vessels in vivo. Microvas Res 2010, 80:23-30.

116. Kuraitis D, Hou C, Zhang Y, Vulesevic B, Sofrenovic T, McKee D, Sharif Z, Ruel M, Suuronen EJ: Ex vivo generation of a highly potent population of circulating angiogenic cells using a collagen matrix. J Mol Cell Cardiol 2011, 51:187-197.

117. Bleiziffer O, Hammon M, Naschberger E, Lipnik K, Arkudas A, Rath S, Pryymachuk G, Beier JP, Stürzl M, Horch RE, Kneser U: Endothelial progenitor cells are integrated in newly formed capillaries and alter adjacent fibrovascular tissue after subcutaneous implantation in a fibrin matrix. J Cell Mol Med 2011, 15:2452-2461.

118. Ferreira LS, Gerecht S, Fuller J, Shieh HF, Vunjak-Novakovic G, Langer R: Bioactive hydrogel scaffolds for controllable vascular differentiation of human embryonic stem cells. Biomaterials 2007, 28:2706-2717.

119. Zamora PO, Eshima D, Graham D, Shattuck L, Rhodes BA: Biological distribution of 99mTc-labeled YIGSR and IKVAV laminin peptides in rodents: 99mTc-IKVAV peptide localizes to the lung. Biochim Biophys Acta 1993, 1182:197-204.

120. Tsilibary EC, Reger LA, Vogel AM, Koliakos GG, Anderson SS, Charonis AS, Alegre JN, Furcht LT: Identification of a multifunctional, cell-binding peptide sequence from the a1(NC1) of type IV collagen. J Cell Biol 1990, 111:1583-1591.

121. Yamamoto M, Yamamoto K, Noumura Y: Type I collagen promotes modulation of cultured rabbit arterial smooth muscle cells from a contractile to a synthetic phenotype. Exp Cell Res 1993, 204:121-129.

122. Hocking DC, Sottile J, McKeown-Longo PJ: Activation of distinct a5b1mediated signaling pathways by fibronectin's cell adhesion and matrix assembly domains. J Cell Biol 1998, 141:241-253.

123. Alobaid N, Salacinski HJ, Sales KM, Ramesh B, Kannan RY, Hamilton G, Seifalian AM: Nanocomposite containing bioactive peptides promote endothelialisation by circulating progenitor cells: an in vitro evaluation. Eur J Vasc Endovasc Surg 2006, 32:76-83.

124. Blindt R, Vogt F, Astafieva I, Fach C, Hristov M, Krott N, Seitz B, Kapurniotu A, Kwok C, Dewor M, Bosserhoff AK, Bernhagen J, Hanrath P, Hoffmann R, Weber C: A novel drug-eluting stent coated with an integrin-binding cyclic Arg-Gly-Asp peptide inhibits neointimal hyperplasia by recruiting endothelial progenitor cells. J Am Coll Cardiol 2006, 47:1786-1795.

125. Kim KL, Han DK, Park K, Song SH, Kim JY, Kim JM, Ki HY, Yie SW, Roh CR, Jeon ES, Kim DK, Suh W: Enhanced dermal wound neovascularization by targeted delivery of endothelial progenitor cells using an RGD-g-PLLA scaffold. Biomaterials 2009, 30:3742-3748.

126. Fusenig N, Marmé D: Tumor Angiogenesis: Basic Mechanisms and Cancer Therapy. Springer 2008, Chapter 17.

\section{doi:10.1186/1755-1536-5-4}

Cite this article as: Caiado and Dias: Endothelial progenitor cells and integrins: adhesive needs. Fibrogenesis \& Tissue Repair 2012 5:4.

\section{Submit your next manuscript to BioMed Central and take full advantage of:}

- Convenient online submission

- Thorough peer review

- No space constraints or color figure charges

- Immediate publication on acceptance

- Inclusion in PubMed, CAS, Scopus and Google Scholar

- Research which is freely available for redistribution

Submit your manuscript at www.biomedcentral.com/submit
Ciomed Central 